\title{
ARGENTINA AND THE HICKENLOOPER AMENDMENT
}

In 1962 section 620 of the Foreign Assistance Act of $1961^{1}$ was amended to add subsection (e). ${ }^{2}$ The main thrust of this subsectionor the Hickenlooper Amendment, as it came to be called-is to place the President under a duty to suspend aid to any country which expropriates American-owned assets without paying "speedy compensation

175 Stat. 424, 444-445 (1961).

276 Stat. 260-61 (1962), as amended, 22 U.S.C. $\$ 2370$ (e)(1) (1964). Hereinafter, this section is referred to as "the Hickenlooper Amendment" or "the amendment." The present form of the Hickenlooper Amendment, as amended, is as follows:

(e) (1) The President shall suspend assistance to the government of any country to which assistance is provided under this chapter or any other Act when the government of such country or any government agency or subdivision within such country on or after January 1, 1962-

(A) has nationalized or expropriated or seized ownership or control of property owned by any United States citizen or by any corporation, partnership, or association not less than 50 per centum beneficially owned by United States citizens, or

(B) has taken steps to repudiate or nullify existing contracts or agreements with any United States citizen or any corporation, partnership, or association not less than 50 per centum beneficially owned by United States citizens, or

(C) has imposed or enforced discriminatory taxes or other exactions, or restrictive maintenance or operational conditions, or has taken other actions, which have the effect of nationalizing, expropriating, or otherwise seizing ownership or control of property so owned,

and such country, government agency, or government subdivision fails within a reasonable time (not more than six months after such action, or, in the event of a referral to the Foreign Claims Settlement Commission of the United States within such period as provided herein, not more than twenty days after the report of the Commission is received) to take appropriate steps, which may include arbitration, to discharge its obligations under international law toward such citizen or entity, including speedy compensation for such property in convertible foreign exchange, equivalent to the full value thereof, as required by international law, or fails to take steps designed to provide rehef from such taxes, exactions, or conditions, as the case may be; and such suspension shall continue until the President is satisfied that appropriate steps are being taken, and no other provision of this chapter shall be construed to authorize the President to waive the provisions of this subsection.

Upon request of the President (within seventy days after such action referred to in subparagraphs (A), (B), or (C) of this paragraph), the Foreign Claims Settlement Commission of the United States (established pursuant to Reorganization Plan No. 1 of 1954, 68 Stat. 1279) is hereby authorized to evaluate expropriated property, determining the full value of any property nationalized, expropriated, or seized, or subjected to discriminatory or other actions as aforesaid, for purposes of this subsection and to render an advisory report to the President within ninety days after such request. Unless authorized by the President, the Commission shall not publish its advisory report except to the citizen or entity owming such property. There is hereby authorized to be appropriated such amount, to remain available until expended, as may be necessary from time to time to enable the Commission to carry out expeditiously its functions under this subsection. 
for such property in convertible foreign exchange, equivalent to the full value thereof." $" 3$

The Hickenlooper Amendment presents many difficult problems of statutory interpretation. However, because the history and mechanics of the amendment have been thoroughly treated elsewhere, ${ }^{4}$ this Comment shall examine only the problems existing after a determination to invoke the provisions of the amendment has been made. These problems fall into three categories: (1) the amendment's efficacy in the attainment of its own goals; (2) its basis in international law; and (3) alternatives to the amendment's method of dealing with expropriation.

The first problem, that of efficacy, is discussed because it has become increasingly clear that the Hickenlooper Amendment has not been able to achieve its goals. The main goal of the amendment is to protect the property of United States citizens, citizens whom Congress has encouraged to invest abroad. ${ }^{5}$ However, neither the threat nor the reality of aid termination has been able to prevent acts of expropriation; nor has the use of aid as a pressure tool succeeded in forcmg aid recipients to meet the amendment's demand for "speedy," "full value" compensation in "convertible foreign exchange."

There is no lack of factual evidence to support the conclusion that the amendment has failed to achieve its goals. At least four similar case histories from around the world (Argentina, Brazil, Ceylon and Indonesia) reveal a consistent pattern of failure. ${ }^{7}$ This factual pattern demonstrates the amendment's failure to provide the flexibility and subtlety so necessary in international affairs; it also reveals the fundamental inability of Congress unilaterally to dictate international behavior in an area so sensitive and controversial as expropriation.

This Comment analyzes the history of an expropriation of contract rights by Argentina in 1963. Apart from being a typical example of the amendment's pattern of failure, the Argentine case was selected for two reasons. First the amendment's chief sponsor, Senator Hickenlooper, stated $^{8}$ that Argentina was a perfect example of a situation to which

${ }^{3}$ See text accompanying notes 110-11 infra, for an analysis of this phrase. The amendment permits the calculation of "full value" to be done by the President or by the Foreign Claims Settlement Commission at the President's request.

4 E.g., Linurch, The Protection of Foreign Investament 117-46 (1965) [hereinafter cited as LIIITCH, Protectron].

5 This is the objective stated by the amendment's chief sponsor, Senator Hickenlooper. 109 Cong. Rec. 21763 (1963).

6 An actual termination of aid unay be somewhat effective to force the payment of some kind of compensation. However, it has never been able to compel "speedy compensation . . . in convertible foreign exchange, equivalent to the full value."

7 A brief description of all four cases is contained in Lincrar, Protecrion 141-45.

8109 CONG. REC. 21761 (1963). 
the contracts clause ${ }^{9}$ of the amendment applied. Second, Argentina is one of the strongest and most important nations in this hemisphere; if the amendment could successfully coerce Argentina, it probably could achieve the same success anywhere in Latin America.

The analysis of the second problem area of the amendment-its basis in international law-is designed to show that even if the concept of using aid as a lever could be applied effectively, it nevertheless should not be applied. The specific legal justification contained in the amendment for its use of economic force is that the expropriating nation has violated what Congress considers to be international law. The rule of law specifically asserted by Congress in the amendment is that compensation for any taking must be "speedy" and must be paid in "convertible foreign exchange equivalent to the full value thereof." If If steps are not taken within six months to conform to this "rule," the amendment becomes operative. As demonstrated in part II of this Comment, this congressional rule for the standard of compensation does not enjoy the status of a rule of international law. While there is much authority in international law for this standard of compensation, ${ }^{11}$ it is still only one of many competing rules in an area of international law where there is no controlling rule. ${ }^{12}$ Therefore, the amendment's pivotal justificationmerely demanding what international law already requires-is neither convincing nor viable.

The final problem area to be explored-alternatives to the Hickenlooper Amendment-is an analysis of other methods for the protection of private foreign investment. Writers on this subject have suggested numerous alternative methods and theories that do not involve the use of force. The more incisive and potentially useful alternatives are based

977 Stat. 387 (1963), 22 U.S.C. \& 2370 (e)(1)(B) (1964). The full text is quoted in note 2 supra.

10 There is another rule implicit in the amendment. This is the rule which authorizes the use of force in reprisal for wrongs done by another nation. See BISHOp, InTERNATIONAL LAw 744 (2d ed. 1962) [hereinafter cited as BISHOP] for the general rules on reprisals and "retorsion." Whatever self-help rights such general rules may give the U.S., these rights may be partly or wholly destroyed by certain treaty commitments to the doctrine of nonintervention and to prohibition against economic coercion. See, e.g., Charter of the Organization of American States, 1948, arts. 15, 16, and 18, T.I.A.S. No. 2361, 18:1 Dep't State Bull. 666 (April 30, 1948), and Convention on Rights and Duties of States, Dec. 26, 1933, arts. 8 and 11, 49 Stat. 3097 , T.S. No. 881.

In addition, the amendment raises the question of the scope of Congress's constitutional power over foreign affairs. As with the question of possible treaty bimitations on the right of reprisal, so also the question of separation of powers is an independent topic beyond the scope of this Comment.

11 See notes 110-11 infra.

12 See note 107 infra. Even if there were a controlling rule and even if the United States adopted that rule, it is still possible that the use of economic force would violate United States treaty obligations. See note 10 supra. 
upon a functional approach to the relationship between national sovereignty and alien property rights. That is, they state the expropriation issue in terms of what solution will best facilitate the growth of the local economy and in turn the world economy. In the final analysis, stating the issue in that form is probably the only way to strike an acceptable compromise between the objectives of the Hickenlooper Amendment and the objectives of the recipients of foreign aid.

\section{I}

THE AMENDMENT'S EFFICACY: THE ARGENTINE CASE

The confrontation between Argentina and the Hickenlooper Amendment occurred in two phases. The first phase concerned the act of expropriation: the revocation by Argentina of contracts to which American compames were parties. The second pliase concerned the use of aid pressure to force Argentina to pay "speedy," "full value" compensation. The hink between these two phases, and the key to the entire affair, was that Argentina had persuasive reasons for declaring the contracts void and for refusing to pay "speedy," "full value" compensation; these reasons hardened into firm convictions which the amendment's techmique of public intimidation could not weaken.

\section{A. Phase I: The Act of Expropriation}

In 1958 the Argentine oil industry was a burden on that nation's economy. Consumption of oil greatly exceeded production, resulting in imports of 182,000 barrels per day. ${ }^{13}$ Such extensive imports cost Argentina 250 million dollars a year and disrupted the nation's monetary stability. ${ }^{14}$

To remedy this dire economic condition, newly elected President Arturo Frondizi embarked upon his "batalla del petroleo" in July 1958.15 This program consisted of a series of concession contracts for development and production signed between 1958 and 1961 with several American and Argentine oil compamies. ${ }^{16}$ The most important of these contracts were those which assigned to private companies specific geographical areas to develop. ${ }^{17}$

The granting of concession rights for oil production marked a sig-

13 N.Y. Times, Oct. 20, 1963, § 3, p. 13, col. 1.

14 Ibid.

15 Jorge del Río, Revocación por ilegitimidad de los "contratos" petroleros, 110 LA LEy, REv. JuRfidica ARgentiNa 1079, 1081 (1963).

16 N.Y. Times, Nov. 1, 1963, p. 45 , col. 4.

$17 \mathrm{Ibid}$. The terms of the three biggest contracts are reproduced in Leopoldo Borini, Tres contratos sobre petróleo, 108 LA LEY, REV. JURiDICA ARGENTINA 1192, 1194-1213 (1962). Two of these also appear in 3 INT'L L. MAT. 359-70 (1964). 
nificant departure from established Argentine policy. Previously, Argentina had flatly refused to allow foreign companies to develop her oil and gas resources; ${ }^{18}$ this function had been within the exclusive domain of the state oil agency, Yacimientos Petroliferos Fiscales (YPF).

Almost immediately there was a flood of criticism of Frondizi's new oil policy. The Communists broke with the Government, ${ }^{10}$ and there was a protest strike by the oil field and refinery workers. ${ }^{20}$ The opposition parties demanded that the contracts be submitted to Congress for approval, ${ }^{21}$ and soon objections were voiced to particular terms in the contracts. ${ }^{22}$

The initial storm of protest subsided somewhat from 1959 to 1962. But on March 28, 1962, President Frondizi was deposed by the military, ${ }^{23}$ and once again the contracts came under open attack. In November 1962 , YPF began an inquiry into the entire affair, ${ }^{24}$ and the presidential elections of 1963 brought inflammatory campaign speeches. The Popular Radical Party's candidate, Dr. Arturo Illia, promised to annul the contracts which he termed "behind-doors deals that had dirty aspects." ${ }^{25}$ Labor leaders branded the contracts as a "sellout" to American imperialism. ${ }^{26}$ In October 1963, a national board investigating administrative procedures released a blistering attack on the contracts. ${ }^{27}$

The substance of the criticism was based upon both economic and legal ${ }^{28}$ grounds. The economic criticisms focused on three ways in which the contracts resulted in substantial losses to the nation. First, it was argued that the foreign companies received an excessive price for the oil they produced. The companies delivered oil to YPF at a set price ${ }^{20}$ which, depending on the contract, was as much as five times what it cost YPF to produce the same oil. ${ }^{30}$ Second, it was argued that the

18 N.Y. Times, Nov. 7, 1962, p. 61, col. 4.

10 Id., Aug. 4, I958, p. 39, col. 5.

20 Id., Nov. 1, 1958, p. 4, col. 5.

21 Id., Aug. 4, 1958, p. 39, col. 5 .

22 Id., Aug. 11, 1958, p. 30, col. 2.

23 See generally Pende, Argentina 144-46 (3d ed. 1963).

24 N.Y. Times, Nov. 7, 1962, p. 61, col. 4.

25 Id., June 16, 1963, p. 28, col. 1.

26 Id., April 8, 1963, p. 68, col. 1.

27 Id., Oct. 10, 1963, p. 11, col. 1 .

28 The legal grounds are discussed in part II of this Comment which demonstrates, among other things, that the contracts may well have been void $a b$ initio under Argentine law and that Argentina's position under international law was thereby strengthened.

20 These set prices bore no relation to the cost of production. Rather, they were based upon the international inarket price as it was on the date of signing. Adolfo Silenzi de Stagni, Los contratos de explotación de petróleo, 109 LA LEY, Rev. JuRídica ARGenTINA 1142, 1147-48 (1963).

30 Del Rio, supra note 15, at 1081. YPF had to pay at the well, before any delivery costs, $\$ 10-\$ 12$ per unit for oil which costs $\$ 2-\$ 5$ per unit to extract. Jorge del Rfo, 
contracts made no provision for transport to or storage at the refineries ${ }^{31}$ and that, as a result, YPF paid for great quantities of oil which were promptly lost by evaporation. ${ }^{32}$ Third, "irrational exploitation" by the companies did substantial damage to the oil fields. ${ }^{33}$

These three sources of loss were compounded because YPF was obligated to accept all of the privately produced oil. This obligation resulted in a flooding of YPF's capacity, which in turn forced YPF to reduce its own production. Thus, the more expensive oil produced by the companies replaced the cheaply produced oil. ${ }^{34}$ Moreover, the risks taken by the companies were low, because they were assigned areas on which very favorable geological studies had already been conducted..$^{35}$

The conclusion of the critics was that the companies were "making a killing" at Argentina's expense. ${ }^{36}$ At various times the companies denied the allegations against them and sought to defend the contracts, ${ }^{37}$ but their pleas were to no avail. While the truth of the allegations has never been ascertamed, the people and government of Argentina were firmly convinced that the contracts were intolerable. ${ }^{38}$ The strength of this feeling and its import for the future became apparent in October 1963 when the president of YPF announced that threats to suspend aid would in no way deter Argentina. ${ }^{39}$ This prophecy proved to be an accurate forecast; the threat to extend the amendment to include contract rights failed to intimidate Argentina. Indeed, by what was probably not a chance coincidence, the contracts clause of the amendment passed the United States Senate on the sanie day that the revocation decree ${ }^{40}$ was issuedNovember 15, 1963. ${ }^{41}$ Having failed to deter revocation, it now remained to be seen whether the amendment would also fail to coerce payment of "speedy compensation . . . equivalent to the full value."

\section{B. Phase II: Compensation}

In view of the strong convictions held by the Illia Government, Argentina's reaction to the idea of coerced compensation was predictably

Renegociación de los "contratos" petroleros, 112 LA LEx, REv. JuRónica ARgentina 849, 851 (1963).

31 Del Río, supra note 15 , at 1080.

32 Id. at 1081 .

33 N.Y. Times, Dec. 18, 1963, p. 63, col. 2.

34 Del Río, supra note 15 , at 1081 .

35 These studies indicated at least a $90 \%$ chance of striking oil. Silenzi, supra note 29, at 1143.

36 N.Y. Times, July 30, 1963, p. 35, col. 1.

37 See, e.g., N.Y. Times, July 30, 1963, p. 35, col. 1; id., Oct. 20, 1963, § 3, p. 13, col. 1 ; id., Nov. 1, 1963, p. 47 , col. 4.

38 See text accompanying notes 19-27 supra.

39 N.Y. Times, Oct. 25, 1963, p. 41, col. 2.

40 This was Decree No. 744/63, reprinted in 3 INT'L L. Mar. 1-10 (1964).

41 N.Y. Times, Nov. 16, 1963, p. 1, col. 1. 
hostile. On November 4, the Secretary of Fuel and Power declared that he saw no reason why Argentina should pay any compensation at all. ${ }^{42}$ Shortly after this statement, the United States Under Secretary of State for Political Affairs, W. Averell Harriman, arrived in Buenos Aires.

It was reported that Mr. Harriman's mission was meant to impress upon Argentina that inadequate compensation would probably result in a termination of U.S. aid. ${ }^{43}$ Harriman's sharp warning seems to have inspired some unofficial talk that "the companies will be compensated in accordance with Argentine justice." ${ }^{\prime 4}$ However, when the Argentines were pressed on the standards of "speedy" and "full value" the reaction was one of complete defiance. It was announced that "payment, if any, will be small." ${ }^{45}$ The Minister of Energy and Fuels, with the backing of Vice President Perette, ruled out all hope of renegotiation of the contracts. ${ }^{46}$ The Foreign Minister warned that before the United States became so committed to the idea of retaliation, Washington would be well advised to consider the vulnerability of the remaining American investments. ${ }^{47}$ Moreover, he stated that Argentina did not need to continue its imports from the United States and that "if the U.S. should cut off credit, Argentina will seek credit in other banks." 48

The threats and counter-threats having produced a stalemate, Argentina filed suit in the local courts on November 18, 1963, to determine the validity of Argentina's claims against the companies. ${ }^{40}$ Answers were duly filed the next month, ${ }^{50}$ and in January 1964, negotiations for an out-of-court settlement began. ${ }^{51}$

As the negotiations dragged on, it soon became apparent that the amendment would disrupt the peace once again. In April 1964, a loan agreement with the Agency for International Development (AID) was

42 Id., Nov. 5,1963 , p. 48 , col. 4.

43 Id., Nov. 9, 1963, p. 11, col. 6 .

44 Id., Nov. 11, 1963, p. 12, col. 3.

45 Ibid.

46 Id., Nov. 15, 1963, p. 54, col. 1 .

47 For example, there remained large investments in shipping, chemicals and automobiles.

N.Y. Times, Nov. 20, 1963, p. 1, col. 5.

48 Id., p. 12, col. 3 .

49 Id., Nov. 19, 1963, p. 14, col. 3. Separate complaints were filed against each of the companies. A representative complaint appears in 3 INT'L L. MAT. 112-14 (1964).

50 One of the answers is printed in 3 INT'x L. MAT. 292-304 (1964).

51 N.Y. Times, Jan. 23, 1964, p. 42, col. 4. It is difficult to verify any explanations for this rather sudden switch from adamant defiance to a mood favorable to negotiations. However, there are at least two probable reasons. First, the United States stopped issuing threats, so the source of irritation was ehminated. Second, the assassimation of President Kennedy interrupted the hives of most people and may well have quelled the heated emotions. 
signed, but no action was taken for almost a year despite "repeated appeals" by Argentina. ${ }^{52}$ By February 1965, Argentina began to sense that United States aid disbursements were being stalled in order to force a settlement, ${ }^{53}$. and the Government made public its anger and confusion over this continued reprisal. The Minister of Economy, Dr. Juan Carlos Pugliese, warned that, if it turned out that the delay was related to the settlement negotiations, "there might be disagreeable political repercussions that could easily damage our good relations." ${ }^{254}$

The final stage of the crisis had been reached; the United States was now forced to clarify its aid policy. The amendment demanded that aid be terminated, but Argentina's intransigence militated for a more moderate response. Fortunately, the final decision was simply to ignore the amendment. Ambassador Edwin M. Martin and Walter W. Rostow, Clairman of the State Department's Policy Planning Council, publicly assured President Illia that the delays were unrelated to the negotiations and that aid payments would continue, ${ }^{55}$ in spite of the major outstanding claims. The amendment had run its course; the diplomats could not reason their way into a decision to invoke it.

Eight months later, in October 1965, out-of-court settlements were finally reached with the major claimants. ${ }^{56}$ From the available facts, four general observations may be made about the terms of these agreements. ${ }^{57}$ First, no rules governing compensation are explicitly recognized. Second, payment is to be made in ten annual installments over the next decade. Third, payment is to be in United States dollars. Fourth, the total amount of the compensation seems to be approximately 110.6 million dollars.

It is clear that these settlement terms do not meet the demands of the Hickenlooper Amendment with the exception of the convertible foreign excliange requirement: Payment will be made in dollars. But payment will not be "speedy"; there were two years of turmoil between the revocation and the agreements, and now ten more years of installments which may or may not be paid. Nor is there any reason to believe that "full value" will be received. The agreements contain no recitation of any effort to ascertain "full value." Moreover, the total figure of 110.6 mil-

62 Id., Feb. 10, 1965, p. 53, col. 2.

53 Ibid.

54 Id., p. 57, col. 7 .

65 Id., Feb. 17, 1965, p. 61, col. 3; id., Feb. 26, 1965, p. 37, col. 2.

${ }^{56} \mathrm{La}$ Nación, Oct. 4, 1965, p. 1, col. 7, and Oct. 11, 1965, p. 1, col. 5 (Buenos Aires, edición aerea internacional). Two settlement agreements are reprinted in 4 INT'x L. MAT. 463 (1965) (an earlier minor claim) and 5 INT'L L. MAT. 103 (1966) (a major claim).

57 See note 56 supra. 
lion dollars is far less than the original total claim, ${ }^{58}$ indicating a definite compromise.

It must be concluded that the amendment failed to achieve its goals. It did not prevent the taking of the American investment; nor did it secure its lofty standards of compensation. It is possible that subsequent use of quiet, subtle aid pressure may have influenced the settlement agreements. But the method of quiet, subtle pressure bears no relation to the amendment's method: Public intimidation and rigid standards proved to be utterly unworkable.

\section{II}

\section{BASIS OF THE AMENDMENT IN INTERNATIONAT LAW}

Even assuming arguendo that the Hickenlooper Amendment is able to coerce "speedy," "full value" compensation, the next question is whether the amendment is correct in its assertion that such compensation is required by international law. Two aspects of the Argentine case raise important questions as to the basis of the amendment in international law. First, were Congress and the Department of State correct that United States citizens possessed legal or equitable rights which could be the subject (res) of a taking? ${ }^{59}$ Second, were Congress and the Department of State correct that international law required "speedy compensation . . . in convertible foreign exchange, equivalent to the full value"? These two questions may be framed in terms of legal issues: 1) When a private alien corporation contracts with a government agency for the right to develop publicly owned natural resources, and subsequently that nation's chief executive revokes the contract as void $a b$ initio for illegality, does international law hold that there has been a compensable taking? 2) If in such a situation there has been a compensable taking, is there a controlling rule of international law which establishes that compensation must be speedy and equivalent to the full value?

\section{A. Was There a Compensable Taking?}

Whether there was compensable taking depends upon which body of law governs the creation of contractual rights, ${ }^{60}$ and upon the content

58 Just prior to the revocation, the companies claimed to have invested $\$ 375$ million and, in addition, that YPF owed them over $\$ 100$ million for delivered oil and services, $\$ 27$ million for a pipeline, and $\$ 27$ million in the form of a loan. N.Y. Tinies, Oct. 26, 1963, p. 33 , col. 3 .

59 The United States did assert that there were such rights. Senator Hickenlooper obviously thought so. See note 8 supra. And, as part I of this Comnient illustrates, so did the Department of State.

60 Quasi-contractual rights are ascertained differently. See text accompanying notes 89-91 infra. 
of that body of law. It is well settled under international law that every contract which is not a treaty is governed by the municipal law of some state, ${ }^{01}$ and that generally the applicable state law is that of the contracting state. ${ }^{22}$ These established rules of choice of law appear to be accepted and espoused by the United States. ${ }^{63}$ They prescribe that an alien acquires no rights under a contract if that acquisition would violate municipal law. ${ }^{64}$ Obviously the oil contracts do not constitute a treaty, so the municipal law of some nation applies. It is clear that Argentine law apphes, because the contracts were signed and performed in Argentina and because the rule which looks to the law of the contracting state has no relevant exceptions. The rights of the United States investors therefore hinge upon the validity of the formation of the contracts under Argentine law.

An examination of the contracts under Argentine law provides substantial support for the argument that the contracts were void for illegality. ${ }^{65}$ The opponents have been able to cite a devastating list of rules and concepts which were violated, and inost of the items on that list have never been controverted in print by the companies. ${ }^{66}$

61 Case of Serbian Loans, P.C.I.J, ser. A, No. 20 at 41 (1929).

62 International Law Comm'n, Report, U.N. GeN. Ass. Ors. Rec. 11th Sess. 71 (A/CN.4/119) (1959); I SchWARTZENBERGER, INTERNationaI LAw 146 (3d ed. 1957). These are, of course, rules of conflict of laws, otherwise known as private international law.

63 On the use of mumicipal law, see Note from the U.S. Ambassador to Cuba to the Cuban Ministry of Foreign Relations, 43 DEP'T STate BuLx. 141 (1960). However, sometimes the United States has preferred to leave these conflicts issues open. See, e.g., The Economic Agreement of Bogotá, signed at the Ninth International Conference of American States (1948), printed in Ninth International Conference of American States, Report of the U.S. Delegation with Related Documents, Dep't State Pub. No. 2363 (1948), especially arts. 22 and 24 at pp. 207-08.

On the selection of which nation's mumicipal law, see RestatenneNT (SECOND), ForeigN ReLatrons LAW of the United States, § 9, comment d; $\$ 194$, comment a; and $\S 195(2)$, comment c (1965).

64 International Law Comm'n, Report, supra note 62, at 60. Accord, Restatearent (SeCond), Foreign Rejations LaW of the Unired States \$ 195(2), comment c (1965). This general rule of non-acquisition has traditionally been subject to a significant limitation, the so-called "minimum standard of international law," which "in substance . . . approximates to the minimum requirements of the rule of law in the Anglo-American sense of the term." 1 Scewartzenberger, op. cit. supra note 62, at 201. In other words, the local law must be applied evenly and fairly in judging an alien's rights. However, this minimum standard, as a limitation on the general rule of non-acquisition, has never been held to prevent regular local courts from determining that a state contract was void $a b$ initio and that, therefore, the alien could not acquire any benefit-of-the-bargain rights.

65 The author is indebted to numerous Argentine lawyers on both sides of the dispute for their assistance in evaluating the legal arguments. This assistance was given during informal conversation and, for obvious reasons, cannot usefully be cited by source. However, whenever an observation about the legal arguments is derived from personal conversations with these attorneys, it shall be so noted. Due to the out-of-court settlements, no court passed upon the soundness of the legal arguments.

66 Only the alleged violations of the Mining Code were controverted. Reply of Ar- 
The basic void-for-illegality argument was premised upon both failure to obtain approval of the Argentine Congress and a wide variety of statutory violations. Congressional approval, the first and perhaps the more frequently cited ground, was necessary because the contracts contained a defect which only Congress could rectify: The official who signed the contracts had no legal authority to do so. As explained in the annulment decree, the proper method for appointing the YPF Board was established in congressional acts relating to the charter of YPF and to the general "Ministries Law." Moreover, the Argentine Constitution prolibited attempts to modify such acts by means of an executive decree. $^{68}$ In utter disregard of the constitutional prohibition and the statutory procedure, the entire YPF Board "resigned" in May 1958, and, by decree, President Frondizi appointed what he called his "personal delegates."60 Without waiting for congressional approval of these irregular appointments, a de facto chairman of the "personal delegates" proceeded to sign the contracts. ${ }^{70}$ Thus, the contracts were signed by a man whose appointment had no validity in law and who, therefore, lacked actual authority.

It is unclear whether Argentime law required congressional approval of both the appointment of the YPF Board and of any attempt by the executive to permit foreign exploitation of Argentine oil resources. There appears to be a custom in Argentina that large contracts with the government may be negotiated and that work may begin prior to obtaining congressional approval. ${ }^{71}$ However, there is evidence that petroleum contracts are an exception to this custom of proceeding with development while ratification is pending. In 1955, shortly before his ouster, Juan Perón had negotiated a contract with Standard Oil of California; the Argentine Congress refused to ratify it, and further progress on the contract ceased..$^{72}$ If the Standard Oil incident evidences a custom with the

gentina Cities Service Development Co., 3 INT'x I. Mar. 292, 299 (1964). Not all the contracts violated all of the rules and concepts; some of the contracts violated almost every item on the list, and some violated none of the items. Personal interview, note 65 supra. However, none of the procedural documents involved in the revocation controversy have bothered to raise this point. Instead, the opponents simply listed all the alleged violations, and the companies took no steps to demand more clarity. See, e.g., the annulment decree, the complaint filed in the courts by Argentina, and the companies' replies in 3 INT'L I. MAT. 1-12, 112-14, 292-304 (1964).

67 Decree of Annulment, 3 IrrT'x L. MAT. 1-2 (1964).

68 Ibid. Cf. Adolfo Silenzi de Stagni, Los contratos de explotación de petróleo, $109 \mathrm{L \Lambda}$ LEY, REv. JURíDICA ARGENTINA 1142, 1161 (1963).

69 Note 67 supra; Silenzi, supra note 68 , at 1161.

70 N.Y. Times, Oct. 10, 1963, p. 11, col. 1.

71 Personal interview, note 65 supra. That custom may lave the force of law, see, e.g., Friedmann, Legai Theory 203 (4th ed. 1960).

72 N.Y. Times, Oct. 20, 1963, § 3, p. 13, col. 1. 
force of law, perhaps ratification on the merits of the oil contracts was also necessary.

The second major ground of the void-for-illegality argument was a miscellaneous group of departures from the terms of various codes and statutes. The departures remained illegal, because congressional authorization for them was not obtained. ${ }^{73}$ The first departure was that most of the contracts extended beyond the twenty-year limitation ${ }^{74}$ provided by the Civil Code. ${ }^{75}$ Second, the Mining Code declared that the national and provincial governments had the power to regulate oil production, taking into consideration such factors as the capacity of the industry and the physical characteristics of the exploited area. ${ }^{76}$ The contracts violated this reserved power by obligating YPF to accept all the oil produced ${ }^{77}$ and by prohibiting any governmental interference with production. ${ }^{78}$ Third, the contracts obligated the Banco Central de la República Argentina and the Banco de Crédito Industrial to provide free access to their exchange reserves. ${ }^{79}$ The charters of both banks forbade any such broad agreement to provide indefinite amounts of foreign exchange. ${ }^{80}$ Fourth, some of the exploitation areas were located in the provinces of Clubut and Santa Cruz; the constitutions of both provinces forbade any private oil production whatsoever. ${ }^{81}$ Fifth, on November 12, 1958, Congress passed Ley 14.773, the Nationalization of the Petroleum Act, article 3 of which states that private rights vested only prior to May 1, 1958, would be respected..$^{82}$ The act made no special provision for the development contracts. These five violations along with numerous others ${ }^{83}$ led

73 Silenzi, supra note 68 , at 1169 .

74 The contracts ran from 20-40 years. Silenzi, supra note 68 , at 1147 .

75 Código Crvir de IA República ARgentina art. 2828 (1953); Silenzi, supra note 68, at 1169. However, it has been suggested that government contracts may be outside the scope of the Civil Code. Personal interview, note 65 supra.

76 Código de Minería de IA Repúbutca ARgentina art. 393 (Buenos Aires 1950) [hereinafter cited as CónIGo MTNERÍA].

77 There were stiff penalties provided for any refusal to accept the oil. These penalties ranged from an extension of the contracts for one month for every ninety cubic meters of oil refused, to exporting and selling the oil on YPF's account. Silenzi, supra note 68, at 1149.

78 Id. at 1167; accord, Bercaitz, Los contratos de petróleo, 111 LA LEX, REv. JuRímIcA ARgentina 1050, 1067 (1963).

70 Silenzi, supra note 68 , at 1164 .

80 Id. at 1165 .

81 Id. at 1169 .

824 JURTSPRUdENCIA ARGENTINA 70 (1958).

83 Among the other violations were the following: (1) Código Minería art. 379 required that in order to produce or deal in oil, a company must be a legally constituted Argentine entity. To become such an entity, it is necessary to conply with the CónIGo DE Comercio de LA Repúbrica ARgentina art. 287 (Buenos Aires 1951). This latter article was not complied with, so there was no compliance with article 379. Silenzi, supra note 68, 
one Argentine writer to conclude that the entire situation should be analogized to the common law concepts of "snap-up" acceptances and undue mfluence, because of the obvious one-sidedness of the terms. ${ }^{84}$

The foregoing recitations make it apparent that there were substantial arguments to support the view that the contracts were void for illegality. The companies have not denied these arguments with particularity, but rather have preferred to allege the unconstitutionality of the revocation decree $^{85}$ and to plead their good faith. ${ }^{86}$ The former argument, that such decrees require prior court approval, is very weak, because the Supreme Court of Argentina has consistently held that the administrative branch of the government may, on grounds of illegality, revoke its own acts without seeking prior judicial approval. ${ }^{87}$ Thus, it is relatively clear that the companies did not acquire any contractual rights, because in all probability the contracts were void $a b$ initio under Argentine law. The argument based upon good faith relates to the possibility of establishing equitable rights. Although international law uses the municipal law of Argentina to determine the validity of the contracts, it also recognizes the possibihty of equitable relief. Such relief is given without reference to any particular municipal law and is based upon theories of unjust enrichment, ratification by conduct and estoppel..$^{88}$

These three theories of liability have been used particularly in international arbitration cases. The quasi-contractual theory of unjust enrichment was the essential basis for the decision in Parker $v$. United Mexican States. ${ }^{89}$ In that case the General Claims Commission held that receipt and acceptance of benefits created a "tacit or implied contract even if the individual to whom delivery was made had neither express nor ap-

at 1167; Bercaitz, supra note 78, at 1067. (2) Código Mrnería art. 381 provided absolute limits on the maximum size of an area that may be exploited by any entity. The legal limit of 2,000 hectares (about 5,000 acres) was grossly violated. Bercaitz, supra note 78, at 106\%. A subsidiary of Standard Oil Company (Indiana) was given a 1,000-square-mile area, and a subsidiary of Tennessee Gas Transmission Corporation operated an area of 5,600 square miles. N.Y. Times, Nov. 1,1963 , p. 47 , col. 4. (3) The signing of the contracts by a de facto chairman of XPF violated that agency's collective structure which required that the directors act only "en colegium." Silenzi, supra note 68 , at 1161-62.

84 Silenzi, supra note 68 , at 1172 .

85 Answer of Argentina Cities Service Development Co. in the Federal Court, 3 Inr's L. Mar. 292-304 (1964); N.Y. Times, Nov. 15, 1963, p. 47, col. 4.

86 N.Y. Times, Nov. 1, 1963, p. 47, col. 4; id., Nov. 14, 1963, p. 49, col. 2.

87 See cases discussed in del Río, Revocación por ilegitimidad de los "contratos" petroleros, 110 LA LEY, Rev. JuRídica ARGentTna 1079, 1033 (1963).

88 Meron, Repudiation of Ultra vires State Contracts and the International Responsibility of States, 6 INT'工 \& Comp. L.Q. 273, 280-88 (1957). These three theories of liability may very well be examples of the so-called "general principles of law recognized by civilized "nations." Statute of the International Court of Justice art. 38 (1945).

89 American and Mexican General Claims Arbitration 35, 4 U.N. Rep. Int'l Arb. Awards 35 (1926). 
parent authority to contract." 90 In two other cases, the term "unjust enrichment" was expressly used..$^{91}$

The theory of ratification was applied in Hemming $v$. United States, ${ }^{92}$ where a United States consul, through lengthy correspondence with his Secretary of State, was reasonably led to believe that the Secretary approved of retaining a local attorney to litigate a case for the benefit of the United States. The United States repudiated the contract, and the tribunal held that the United States was hable on the basis of ratification by the conduct of its officials. ${ }^{93}$ The third theory, estoppel, was used in the Shufeldt Claim $^{94}$ which involved a concession contract. The sole arbitrator found the contract to be valid under Guatemalan law, because the legislature of that nation had approved it. ${ }^{95}$ However, $i_{1}$ very strong dicta, he approved the contention that estoppel also validated the contract. Estoppel was found to arise from the following facts: The governnient had (1) recognized the validity of the contract for six years, (2) received all the benefits to which it was entitled under the contract, and (3) allowed the alien to continue to invest capital in the concession. ${ }^{96}$

The application of the reasoning in these cases to the Argentine contracts would appear to create sonie forn of equitable rights, because the Argentine government continued to accept performance from the companies for five years. However, it has been noted that the use of these three theories in international law has generally presupposed the good faith of the alien plaintiff. ${ }^{97}$ Moreover, Secretary of State Rusk, ${ }^{98}$ among others ${ }^{99}$ has observed that an investor should use reasonable care to ascertain the authority of the official with whom he deals. Indeed, it would seem to be quite reasonable to impose a heavy burden of care on the alien in connection with a large concession for the exploitation of another nation's mineral resources. ${ }^{100}$

$80 \mathrm{Id}$. at 40 .

91 General Finance Corp., Dep't of State Arbitration Series No. 9, 546, 548 (1947); Lena Goldfields Ltd. and the Soviet Government (1930), 36 CoRNELI L.Q. 31, 42-53 (1950).

02 American and British Claims Arbitration 620, 6 U.N. Rep. Int'l Arb. Awards 51 (1920).

${ }^{93}$ Id. at 53. See also Jalopa R.R. \& Power Co., Dep't of State Arbitration Series No. 9, 538 (1947).

94 Dep't of State, Arbitration Series No. 3, 851, 2 U.N. Rep. Int'l Arb. Awards 1079 (1930).

${ }_{05}$ Id. at 859-60, 2 U.N. Rep. Int'l Arb. Awards at 1094.

96 Ibid. See also Davies (Umited States v. Mexico), 4 U.N. Rep. Int'l Arb. Awards 169 (1927).

07 Meron, supra note 88 , at 285

98 Rusk, Trade, Divestment and United States Foreign Policy, 47 Dep'T Stare BuLL. 683, 687 (1962).

99 Meron, supra note 88 , at 288.

100 Id. at 289. 
In the case of the Argentine contracts, there is considerable evidence of bad faith or lack of due care, or both, in the conduct of the companies. First, because the contracts were a radical departure from Argentina's exclusively nationalistic oil policy, ${ }^{101}$ the companies should have been sufficiently warned to move very cautiously. Second, the procedure of congressional ratification of oil contracts was not without precedent in Argentina. ${ }^{102}$ Third, the companies must have had ample notice of the strong opposition to the contracts well before the first one was signed. For example, the New York Times in March, 1958, reported not only that Argentine law forbade such contracts but also that two cabinet ministers had resigned to protest the negotiations. ${ }^{108}$ Fourth, in spite of all the controversy over the legality of the contracts, only the company lawyers participated in the drafting. ${ }^{104}$ No lawyers representing the President, YPF, the Treasury, or the Attorney General of Argentina were consulted. ${ }^{105}$ This evidence of carelessness and bad faith would provide a very strong defense against argunents based on the equities of the case.

It nust be concluded that there is no clear case for the recognition of contractual or equitable riglits on the part of the companies. On the contrary, all the persuasive arguments demonstrate that no rights of any sort were ever created. Nevertheless, on the assumption, arguendo, that an Argentine or an international court would have found some rights in the companies, it remains to be seen whether and to what extent international law imposes a duty of compensation upon Argentina for the taking.

\section{B. The Amendment and the International Law of Compensation}

If it can be estabhshed that rights did arise under the oil contracts, there is probably enough evidence to show the existence of a customary rule of international law requiring at least some compensation in such cases. $^{106}$ However, the Hickenlooper Amendment goes beyond stating merely that a duty to compensate exists; the amendment also seeks to define the scope of that duty. The assertion by the amendment that

101 See text accompanying note 18 supra.

102 See text accompanying note 73 supra. Some Argentine citizens say that the companies had actual notice of this required procedure and that they took a conscious risk. Personal interview, note 65 supra.

103 N.Y. Times, March 22, 1958, p. 6, col. 3. Note the contrast between these facts and Senator Hickenlooper's assertion that "everyone accepted the contracts as legal and binding." 109 CoNG. Rec. 21759 (1963).

104 Silenzi, supra note 68, at 1164.

105 Ibid.

108 Bishop 691-92; RestateMtent (SeCOND), Foretgn Reiations LaW of the Untted States § 195(2) (1965). Contra, FriedmanN, Expropriation IN International Law 204 (1953). 
international law requires "speedy compensation . . . in convertible foreign exchange, equivalent to the full value" is perhaps the worst of the amendment's failings, because that assertion is so difficult to sustain. There simply is no controlling standard as to the amount or mode of payment, ${ }^{107}$ and "the so-called international law standards of the Hickenlooper Amendment . . . could not conceivably be maintained in an international adjudication." "108 The well-known controversy over the standard of compensation has a long history; analysis and evaluation of it have been exhaustive. ${ }^{109}$ This Comment shall not reiterate that history; however, a summary treatment is necessary to indicate how the amendment relates to the controversy.

The amendment embodies the traditional United States standard of compensation usually phrased as "prompt, adequate, and effective"; 110 these are also the traditional international standards. ${ }^{111}$ However, at least two other standards have been espoused which directly compete with the traditional rule, ${ }^{112}$ and which belie the assertion that there exists a unified international law of compensation. The general Latin American rule of "national treatment" provides that aliens should be treated as nationals, and that compensation should be no more and no less than what a national would receive. ${ }^{113}$ There is also the view of the Soviet

107 BisHOP 691-92. The conflicting standards ranged from "adequate and effective" to "no duty to pay compensation except as that state's own law may require." Id. at 692.

108 LIIITCH, Protection 189.

109 The best of the recent treatments are the following: Fatouros, International Law and the Third World, 50 VA. L. Rev. 783, 807-808 (1964); Friedmann, The CHangIng StrdCTURE OF INTERNATIONAI LAW 179-81, 205-06, 318-19 (1964) [hereinafter cited as FrIEDManN, StRdCruRE]; Banco Nacional de Cuba v. Sabbatino, 376 U.S. 398, 428-30 (1963). (This case has been refiled on the basis of new legislation not affecting the validity of the discussion regarding compensation standards. Banco Nacional de Cuba v. Farr, 243 F. Supp. 957 (S.D.N.Y. 1965).) It should be added that the out-of-court settlement agreements between the companies and Argentina do not recognize any compensation rules. 4 INT'x L. MAT. 463 (1965) and 5 INr's L. MAT. 103 (1966).

110 LIIITCH, Protection 130-131.

111 The international tradition is to require "just compensation." Fatouros, supra note 109 , at 807 . "Just compensation" has traditionally meant "prompt, adequate, and effective." Restatearent (Second), Foreign Relations LaW of the United States \$§ 185, 187 (1965). The Restatement defines "adequate" as meaning fair narket value plus interest ( $\$ 188(1)$ ) and defines "effective" as meaning cash or property readily convertible into cash (\$190(1)).

112 It may be argued persuasively that the differences in the rules on compensation are directly related to differences in economic theory and in levels of economic development among nations of the world. BRIERLY, THE LAW of Nations 284-85 (6th ed. 1963); FrIEDMANN, StrUCtURE 180.

113 Fatouros, supra note 109, at 807-08; Restateanent (SECOND), Foreign ReLations LAw of the UnTted States \$ 185, Reporters' Notes No. 2 (1965). The Argentine conpany which was involved in the contracts was also sued by Argentina, and that suit was also settled out of court. No special advantages were given the Argentine company; the only difference was that its contract involved few, if any, violations of Argentine law. Personal interview, note 65 supra. 
Union, which contends, in effect, that there is no duty of counpensation. ${ }^{114}$ The conflict among these three competing rules has completely unsettled the international law of compensation. ${ }^{115}$ Since that law is based upon custom, ${ }^{116}$ the controversy has resulted in there being no practice sufficiently well established to constitute an authoritative custom. ${ }^{117}$ Until such time as the sources of international law ${ }^{118}$ identify a controlling rule, international law cannot be said to require any particular compensation standards.

The United States was at no time able to justify its aid pressure on the basis that Argentina violated international law. It is highly doubtful that international law would recognize any rights under the disputed contracts; it is certain that present international law does not recognize the amendment's compensation standards as controlling. Therefore the amendment's claim to be based upon the requirements of international law is mere arrogation and a source of embarrassment which the United States should disavow.

\section{III}

\section{ALTERNATTVES TO THE AMENDMENT}

There are two basic categories of alternatives to the Hickenlooper Amendment. The first category would retain the principle of the amendment but would seek to modify its terms. Possible modifications include relieving the President of his duty to suspend aid by giving him discretion to do so, ${ }^{119}$ establishing as a condition precedent to use of the amendment that the private investor have exhausted his remedies under local law, ${ }^{120}$ and removing the assertion that the amendment's compensation standards are "required by international law." The second category of alternatives envisions total repeal of the amendment; it suggests substitutes which include other methods of obtaining compensation and the adoption of a completely new compensation law.

Although as a matter of practical politics outright repeal is unlikely, ${ }^{121}$ it is submitted that mere modification of the amendment is only

114 Fatouros, supra note 109, at 808.

115 See authorities cited in note 109 supra.

116 See authorities cited in note 106 supra.

117 BISHOP 23-30, 691-92. Nor are there any comprehensive multilateral treaties.

118 See generally BisHop 22-56.

119 LIIITCH, Protection 145.

120 Exhaustion of local remedies is a well-established requirement of international law. See generally BISHOP 704-09. The terms of the amendment appear to depart from this requirement, because the burden seems to be on the other nation to take action rather than on the ahien to exhaust his remedies.

121 LIIIICE, Protecrion 145. Congressional sentiment favorable to the amendment was recently confirmed when the Senate added a similar amendment to the Inter-American Development Bank Act. 111 Cong. Rec. 3519-25 (1965). 
patchwork and that the problem of expropriation has become so complex as to require fresh analysis. Therefore, this Comment shall concentrate upon the more useful and constructive alternatives contained in the second category.

\section{A. Substitute Methods for Obtaining Compensation}

The first type of substitute would provide methods other than unilateral coercion for obtaining compensation. These methods concentrate upon the use of peaceful, international settlement. Prior to the Hickenlooper Amendment, the favorite means of resolving expropriation disputes was resort to diplomatic channels. ${ }^{122}$ The advantage of this approach is that it is flexible, and, because the United States is not dealing with satellites in these cases, flexibility is essential. However, a return to an exclusive reliance upon diplomacy is not advisable; it does not advance international law because it is too vague and uncertain a remedy to qualify as a really useful norn upon which reasonable expectations can be based.

Beyond diplomacy there are specific methods which can provide a degree of certainty. First, the obvious popularity of the post-war bilateral compensation treaties could be utilized. These treaties usually rely upon the concept of unjust enrichment $t^{123}$ which, as a general principle of law, ${ }^{124}$ provides a common ground for analysis and understanding. Second, treaties could also be used to provide a greatly expanded investment msurance program on an international scale. ${ }^{125}$ The use of a general insurance fund would permit the world community to spread the risks of expropriation over all the various economic and pohtical systems. Third, Professor Richard B. Lillich has suggested that the United States Foreign Claims Settlement Commission be empowered to adjudicate the value of a claim prior to the time when settlement negotiations commence. ${ }^{126}$

122 Hearings on S.1276 Before the Senate Committee on Foreign Relations, 88th Cong., Ist Sess. 27 (1963) (testimony of Secretary of State Rusk); Address by Under Secretary Ball, 46 Dep't State Burc. 912, 915 (1962).

123 Jiménez de Aréchaga, The Duty to Compensate for the Nationalization of Foreign Property, U.N. Doc. No. A/CN.4/152, Annex II, at 18, 21 (1963).

124 Statute of the International Court of Justice art. 38 (1945); FRIEDMANN, STRUCrURE 206-10.

125 Fatouros, supra note 109, at 815; Lillich, The Protection of Foreign Investment and the Foreign Assistance Act of 1962, 17 RuTGERs I. REv. 405, 426 (1963). The United States has liad such a program since 1948. Upon payment of the insured's claim, the United States becomes subrogated to the insured, and Washington is then at liberty to compromise the claim. See generally BISHOP 694-95; in Note, Avoiding Expropriation Loss, 79 HARV. L. REv. 1666, 1673-79 (1966), it is argued that, althougl the Umited States program is beneficial, it is perlaps too limited in its coverage. A United States investment guaranty for expropriation is not yet available for Argentina. 5 INT'工 L. MAT. 377 (1966).

126 LrmLich, Protection 172. 
Fourth, the member nations of the World Bank are in the process of establishing an mternational center for the settlement of investment disputes through arbitration and conciliation. ${ }^{127}$

These four substitute methods for obtaining compensation would certainly be an improvement upon the amendment even if they only helped to avoid sabre-rattling. However, even those methods are only vehicles for applying a conceded duty to compensate. As part II of this Comment indicated, there is also a need for substantive law to define the nature and scope of that duty.

\section{B. A New Law of Compensation}

At least two of the outstanding scholars of the international law of expropriation have espoused the idea of a new and separate body of law termed the "Taw of economic development.".128 The three rules currently in force ${ }^{129}$ are victims of a familiar process in the law: Old rules have been rendered anachronistic by changed circumstances. The extant rules were designed to serve the objectives of respect for private property, or the principles of sovereignty and natioual independence. ${ }^{130}$ However, present needs demand that the law serve a new objective-assuring "the optimal development of the world's natural resources consistent with the maximization of benefits to the state and the region in which the resources are located." 131 In other words, the law should protect whatever

${ }^{127}$ International Bank for Reconstruction and Development Convention on the Settlement of Investment Disputes between States and Nationals of Other States (1965), printed in World Peace Through Law Pamphlet Series, No. 2 (1965). A general discussion is contained in Avoiding Expropriation Loss, supra note 125, at 1669-72. Briefly, this Convention would estabish an International Center for the Settlement of Investment Disputes; the Center would be an autonomous international institution, articles 18-24, and would "provide facilities for conciliation and arbitration of investment disputes," article 1(2). Jurisdiction would be consensual, article 25(1), and cases would be decided by Conciliation Commissions and Arbitral Tribunals constituted in accordance with provisions of the Convention. Article 3 requires the Center to maintain panels of conciliators and arbitrators, and article 14(1) seeks to ensure that panel members would possess a bigh degree of competence and objectivity. If the parties select their own bench from outside the Center's panels, articles $31(2)$ and $40(2)$ require that the men selected must meet the qualifications of article 14(1). Final decisions would be enforced as if they were judgments of a court of the party state, article 54(1), subject to the local law of sovereign immunity, article 55 .

It is clear that such a forum would not be used unless the parties could be assured that the law to be applied in each case would give fair and proper weight to all the conflicting interests. Professor Fatouros has suggested a new legal norm which does consider all the interests, see text accompanying notes 133-35 infra, and the Convention's choice of law rules appear to permit use of the Fatouros norm, article 42(1).

128 Fatouros, suppra note 109, at 810; FrIEDMAANr, Structure 176, 179-81, 322.

129 See text accompanying notes 110-14 supra.

130 Fatouros, supra note 109, at 809-10.

131 Id. at 810 . 
serves to achieve economic growth. The current rules do not serve this goal. ${ }^{132}$

The great advantage of framing an expropriation issue in terms of economic growth is that analysis may then be functional rather than nationalistic. Nationahism can produce no consensus, whereas a functional approach is able to focus on the parties' long-range common interest in the economic merits of the case.

Professor A. A. Fatouros has designed a special legal norm, tailormade to fit the "significantly different situation" of the underdeveloped nations. It would require only that the expropriating state act in good faith $^{133}$ and pay fair compensation. ${ }^{134} \mathrm{He}$ suggests a number of criteria by which the "fairness" of the compensation could be judged-for example, the origin of the investment and its possible illegal or unequal beginnings, the financial and economic position of the state concerned, and the kind of enterprise mvolved. ${ }^{135}$ These criteria seek to include all the relevant interests involved in a case of expropriation, but the parties would probably find it difficult to agree upon which of their conflicting interests best serves the goal of economic growth. Perhaps the best forum to render such a decision would be the World Bank's proposed arbitration-conciliation center. ${ }^{136}$

The United States foreign assistance program, and more particularly the Alliance for Progress, should be fully committed to the notion that highest priority goes to the objective of economic development, ${ }^{137}$ and the United States should advocate a new international law based solely

132 The financial burden of the traditional rule "limits the freedom of these countries to take the measures they may later deem necessary for their economic development," and the Latin American and Soviet rules give too little security to the investor. Ibid.

$133 \mathrm{Id}$. at 814 . He adds that only in cases of bad faith would the expropriator be required to pay "full value." Emphasis on the motive behind the taking was also advocated in International Law Comm'n, Report, U.N. GeN. Ass. OFF. REc. 11th Sess. 45 (A/CN./119) (1959).

134 Fatouros, supra note 109, at 814. It is possible that a new test of economic development need not be limited by a duty of compensation. That is, if investment insurance on an international scale could be established, see text accompanying note 125 supra, then a compensation fund would be available, and the rule could be that nations at early stages of growth would be free of any duty to pay, except perhaps when they act in bad faith. Developed nations would have to pay fair market value.

135 Fatouros, supra note 109 , at 814.

136 See discussion of this proposal at text accompanying note 127 supra. If the forum's decision were against the foreign investor, compensation might still be paid from investment insurance, at least absent the investor's bad faith. See note 125 supra.

137 Policy statements to this effect are legion. See, e.g., Title I of the Charter of Punta del Este, 45 Dep't State BuLc. 463 (1961); Address by Secretary Rusk, 45 Dep't State BuLc. 702, 705 (1961); Address by former AID Administrator Bell, 51 Dep'r State Bult. 821 (1964); 110 Cong. Rec. 17167 (1964) (remarks of Sen. Morse). 
upon this same objective. Assuming that private foreign investment is necessary for economic development, ${ }^{138}$ can it be said that the Hickenlooper Amendment advances this development by protecting and therefore encouraging investment? Secretary of State Rusk has refused to endorse the amendment's coercive technique as an effective measure in times of crisis, ${ }^{139}$ and certainly the Argentine case substantiates that refusal. ${ }^{140} \mathrm{~A}$ climate truly favorable to foreign investment cannot be created by force..$^{141}$

\section{CONCLUSION}

Both the method and the law of the Hickenlooper Amendment were unfortunate choices. The method of unilateral force is probably ineffective. The requirement of "speedy compensation . . . in convertible foreign exchange, equivalent to the full value" is an erroneous statement of the law. Congress has available to it numerous constructive alternatives to both the method and the law of the amendment; it has only to recognize them. But whatever decision is made, the legitimate demands of the underdeveloped nations must be met or else the theory and practice of international expropriation law will continue to flounder. Since the United States shares with the underdeveloped nations a strong interest in their economic welfare, perhaps the test of economic development is the best means to an acceptable compromise, for in the long run all nations would benefit.

Stephen R. Luce*

138 Hearings on S.1276, supra note 122, at 30 (testimony of Secretary of State Rusk).

$139 \mathrm{Ibid}$. See also Hearings on S.2996 Before the Senate Committee on Foreign Relations, 87th Cong., 2nd Sess. 557 (1962) (statement of the Department of State).

140 Apart from the ineffectiveness of the amendment as demonstrated in part $I$ of this Comment, retaliation against Argentina was in any event a product of bad judgment. In the entire post-war era, there had been only one other instance of expropriation of American property in Argentina, and that case was amicably settled. 109 Cong. REC. 21775 (1963) (remarks of Sen. Hickenlooper). Furthermore, the Argentine Constitution expressly regulates expropriation and expressly requires compensation. Constitución de la Nación Argentina, Article 17 (1853), in Códigos de La Nación ARgentiva (R. E. Rojas Mery ed. 1929). The Argentine courts regularly deal with expropriation cases, see, e.g., Empresa Nac. de Transportes v. "Astilleros Tigre," 4 JuRisprudencta Aroentina 328 (1964), and Argentine lawyers are of the opinion that the law is well settled. Personal interview, note 65 supra.

141 Brown, The Use of Foreign Aid as an Instrument to Secure Compliance with International Obligations, 58 Axr. Soc. Ivr'工 LAW Proc. 210, 213 (1964). As for creating a climate favorable to public foreign investment (aid), Argentina's foreign minister warned that a termination of aid merely because of Argentina's oil policy would destroy whatever faith there was in the Alliance for Progress. N.Y. Times, Oct. 26, 1963, p. 33, col. 3.

*A.B. Yale University, 1963. IL.B. University of Cahforma, Berkeley, 1966. 